\title{
PVDコーティング手法による(011)〔100]方位の 珪素鋼単結晶上にTiNを成膜したときの集合組織の変化
}

\author{
井口 征夫* \\ Variation of Textures of TiN Deposited on (011) [100] Single \\ Crystal of Silicon Steel due to Difference in PVD Coating Method \\ Yukio INOKUTI
}

Synopsis : In order to clarify the difference in the textures of TiN film due to PVD coating methods, TiN ceramic coating by HCD (Hollow Cathode Discharge) and EB (Electron Beam) + RF (Radio Frequency) methods was done on the surface of polished silicon steel samples. Pole figures of dual textures of the TiN film and related silicon steel samples were measured simultaneously using SSD (Solid State Detector) auto pole figure apparatus.

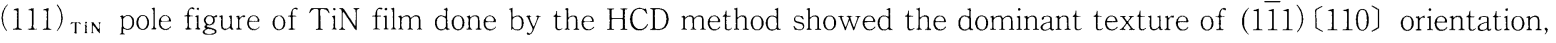
and (100) si-steel pole figure of (011) [100) single crystal of silicon steel showed the dominant texture of (011) [100] orientation, in which two $(220)_{\mathrm{TiN}}$ pole peaks of TiN film on TD axis were detected simultaneously, and their conjugated pole peaks manifested elliptical shape.

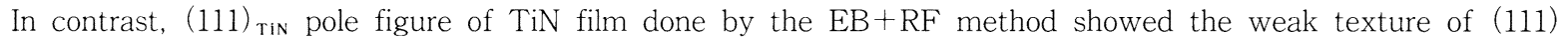
crystallographic plane, and $(100)_{\mathrm{si} \text {-steel }}$ of silicon steel sheet showed the dominant texture of (011) [100] orientation, in which (220) Tin $_{\text {p }}$ pole peaks of TiN film were detected simultaneously, and their conjugated pole peaks also manifested elliptical shape.

It is considered that, due to the higher ionization by the HCD method than that by EB + RF, it was possible for TiN film to form the dominant texture of $(1 \overline{1} 1)[110]$ orientation, resulting in a fine and smooth TiN film with good adhesion, thereby endowing the TiN-coated silicon steel sheet with a reduced iron loss.

Key words : grain oriented silicon steel ; TiN ceramic coating; hollow cathode discharge method; electron beam + radio frequency method; ionization level ; texture of TiN thin film; dual texture; polished surface.

\section{1. 緒言}

最近，研磨により平滑化した一力向性珪素鋼板表面に $\mathrm{P}$ V D (Physical Vapor Deposition) ${ }^{1-3)}$ 用いてセラミック を被覆すると珪素鋼板の鉄損が, 最大で約 $40 \%$ 低減するこ とが報告された。さらに,この珪素鋼板は, (1)高磁束密度, (2)低磁歪特性, (3)高占積㳯等, 現行の珪素鋼板では全く得 られていない優れた特性を示すことも明らかにされた。ま た, PVDでセラミック・コーティングを行う際, HCD(Hollow Cathode Discharge) 法を用いて表面にTiN被覆した一方向 性珪素鋼板では，EB(Electron Beam) +RF (Radio Frequency）法でTiNを被覆した場合よりも磁気特性の向上が 著しいことが明らかにされ コーティング手法の違いによる TiNの膜質(珪素鋼板の表面 近傍に強力な張力付加が可能なセラミック被膜)に起因する と推論された。

本報は, 一台のイオンプレーティング装置内でHCD法と
$\mathrm{EB}+\mathrm{RF}$ 法の二種類の方法を用いて (011)〔100〕方位の珪素 鋼単結晶表面上にTiNを被覆した後SSD (Solid State Detector）付全自動極点図測定装置によりこれら TiN膜 と珪素鋼単結晶の二層の集合組織を同時に測定することに よってイオンプレーティングのコーティング手法による TiN 膜の集合組織の相違を明らかにした。また，両手法におけ るTiのイオン化率を測定してTiNの膜質の相違も比較検討 した。特に，本論文では，コーティング手法によるTiN膜 の集合組織变化を的確に把握するため, 一方向性珪素鋼板 の磁気特性の測定と全自動結晶方位測定装置の使用による 結晶方位情報の両方を駆使して，理想的な(011)〔100〕方位 を有する珪素鋼単結晶を特別に選別してコーティング実験 に用いた。

\section{2. 実験方法}

$0.23 \mathrm{~mm}$ 厚の一方向性珪素鋼板の製品板〔この素材成分は 


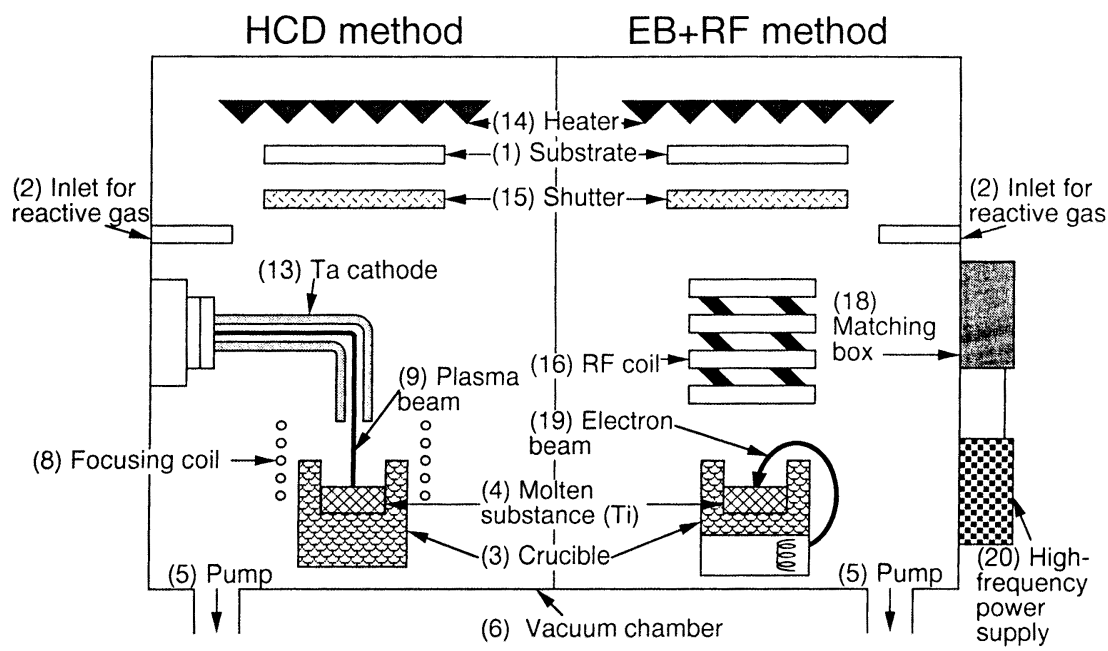

Fig. 1. Schematic diagram of the ion plating apparatus ${ }^{11}$ in which both $\mathrm{HCD}$ and $\mathrm{EB}+\mathrm{RF}$ methods can be used.

C : $0.043 \mathrm{mass} \%$, Si : $3.31 \mathrm{mass} \%$, Mn : 0.072mass\%, Se : $0.019 \mathrm{mass} \%$, Sb : $0.023 \mathrm{mass} \%$, Mo : $0.012 \mathrm{mass} \%]$ を出発素材として用いた。この製品板は $30 \mathrm{~mm} \times 300 \mathrm{~mm}$ に 切断し,その後1073Kで7.2ksの歪み取り焼鈍後, SST (Single Sheet Tester, 単板試験機)で磁気特性を测定した。こ の実験においては, 磁束密度の最良の試料〔 $\mathrm{B}_{8} か ゙(\mathrm{~A}): 1.93$ Tレベル】出の絶縁被膜を溶融 $\mathrm{NaOH}$ 中に浸漬して除去し,さ らに10\% $\mathrm{HCl}(353 \mathrm{~K})$ 中に浸漬してフォルステライト被膜を 除去した。この処理後においては，2次再結晶粒の形状の 判別が可能であるので, 全自動単結晶測定装置)の使用によ り約 $25-30 \mathrm{~mm}$ に大きく成長した 2 次再結晶粒の結晶方位を 測定し, その結晶方位が(011) 面方位から $\mathrm{ND}<1$ 以以内, $〔 100 〕$ 軸方位か $5 \mathrm{RD}<1^{\circ}$ 以内の方位を持つ試料の及を特別 に選別した。別の一方向性珪素鋼板に特有の結晶方位の表 示方法6では，(011）〔100]方位からの擦れの程度を表す $\alpha$, $\beta, \gamma$ の值が何れも $1^{\circ}$ 以内の理想的な (011)〔 100$\rceil$ 方位を有す る 2 次再結晶粒を選別した。その後試料の表面を $3 \% \mathrm{HF}$ と $97 \% \mathrm{H}_{2} \mathrm{O}_{2}$ で化学研磨して表面を平滑にした。なお，化学研 磨後の試料表面は，平滑で光沢のため 2 次再結晶粒を判別 寸ることが不可能となるため, 化学研磨の前には 2 次再結 晶粒の形状を記憶しておく必要がある。

化学研磨後の珪素鋼板表面上:へのTiN被覆は, Fig. 1 の模 式四に示寸イオンプレーテイング装置1を用いて行った。こ の装置は一台のイオンプレーティング装置でHCD法とEB+ $\mathrm{RF}$ 法の二種類の方法でコーティング処理ができるのが特徵 である。さらに,この装置には薄鋼板に0.5 20MPaの引張 張力を付加し，かつ鋼板の表・毫面が均一に成膜できるよ うに一軸回転しながらユーティングできる治具を用いてお ク, 本コーティング実験においては珪素鋼板への張力を 3.5 MPaで行った。

$\mathrm{HCD}$ 法と $\mathrm{EB}+\mathrm{RF}$ 法のイオンプレーティング処理は次に 示寸条件でTiN ニーティング(約 $1 \mu \mathrm{m}$ 厚) を行った。 HCD法 においては投入パワー： $20 \mathrm{~kW}$, 集束コイルパワー: $1.5 \mathrm{~kW}$ ，

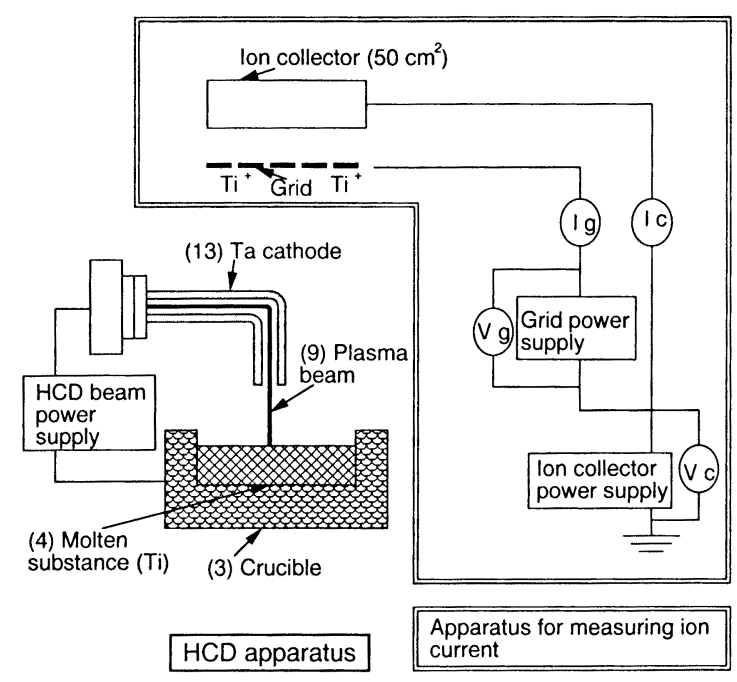

Fig. 2. Schematic diagram showing the method of measuring the ionization rate of Ti atoms on the substrate surface.

操作压力：0.093Pa, バイアス電厓: $-100 \mathrm{~V}$, 基板温度： $673 \mathrm{~K}$, 成膜速度: 約 $0.1 \mu \mathrm{m} / \mathrm{min}$ で行った。次に, $\mathrm{EB}+\mathrm{RF}$ 法ではEBの投入パワー：15kW, RFパワー：0.5kW，操作 压力：0.04Pa, バイアス電座: $:-500 \mathrm{~V}$, 基板温度 : $673 \mathrm{~K}$, 成膜速度: 約 $0.05 \mu \mathrm{m} / \mathrm{min}$ で行った。

Tiのイオン化率は基板に到達するイオン電流を測定する こどによって決定した。Fig. 2 にはHCD法でイオン化率を

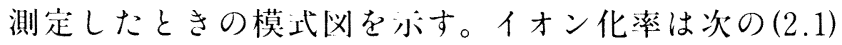
〜 (2.3)により求めた。すなわち, Fig. 2 の中のイオンコレ クターの単位面穔・時間当たりに入射するTi原子の入射頻 度 $\nu_{\mathrm{ri}}$ は

$$
\nu_{\mathrm{Ti}}=\frac{1}{60} \times\left(\mathrm{R} \times 10^{-4}\right) \times \rho_{\mathrm{ri}} \frac{\mathrm{N}_{\mathrm{A}}}{\mathrm{M}_{\mathrm{Ti}}}\left[\text { molecules } \cdot \mathrm{cm}^{-2} \cdot \mathrm{sec}^{-1}\right]
$$

となる7)。ここで， 


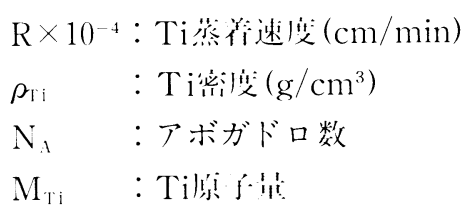

を小注。

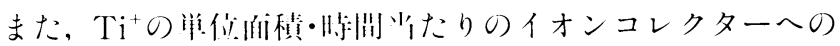
人射频度は

$\nu_{\mathrm{iTi}}=\frac{1}{50} \times \frac{\mathrm{I}_{\mathrm{c}}(\mathrm{Ar}+\mathrm{Ti})-\mathrm{I}_{\mathrm{c}}(\mathrm{Ar})}{1.60206 \times 10^{-19}}$

となる。

ここで, $\mathrm{I}_{\mathrm{c}}(\mathrm{Ar}+\mathrm{Ti})$ は ArおよびTiイオン食体のコレクター

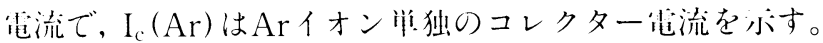

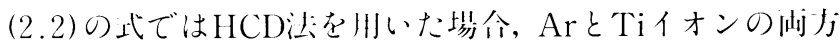

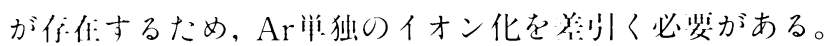
したがって，Tiのイオン化率は

$$
\frac{\nu_{\mathrm{iT}}}{\nu_{\mathrm{Ti}}} \times 100(\%)
$$

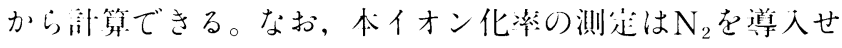

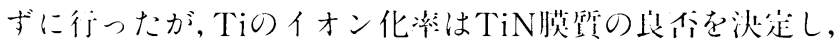
$\mathrm{N}_{2}$ ガスの影留が小さいと考えられる。

次に, EB+RF法のイオン化摔の测定に際しては, Fig. 2

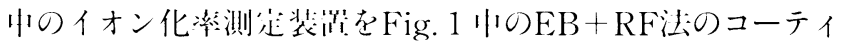

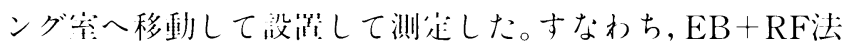
のコーティング剖の（16）のRFコイル，(19)のEB，および

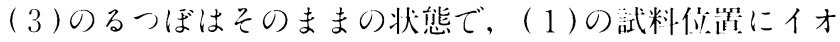

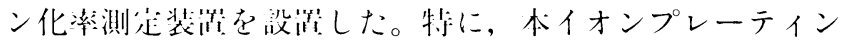
グ装䈐においては，HCD法とEB+RF法によるイオン化㻭

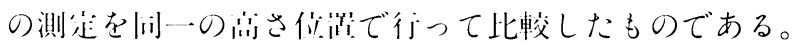

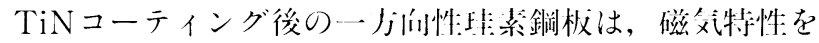

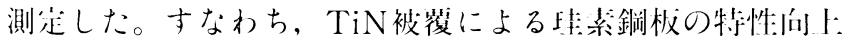

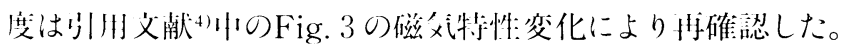
その後, 磁父特性测尘後のエプスタイン试料は, $30 \mathrm{~mm} \times 30$ $\mathrm{mm}$ に切断した。この式料のTiN膜の構适解析は, X線吅折

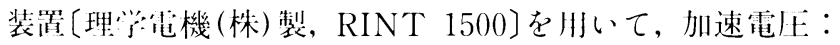
$50 \mathrm{kV}$ ，電流：160mAで，Coターゲットで测定した。

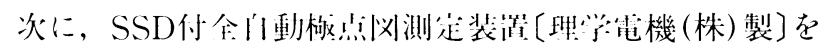

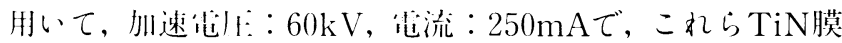
と珪素鎆板の二届の集全組織を间時に测走した。すなわち， これら二为の集价組織は, Fig. 3 に六すX線川折結果とTable 10 TiN $\varepsilon \alpha$-Fe $\sigma$ JCPIDS (Joint Committee on Powder

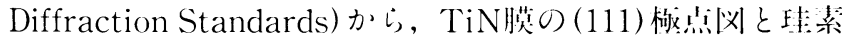

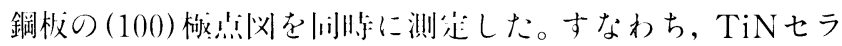

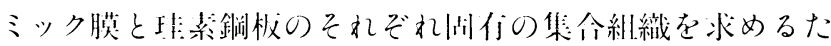

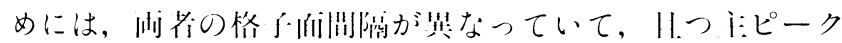

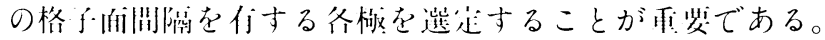
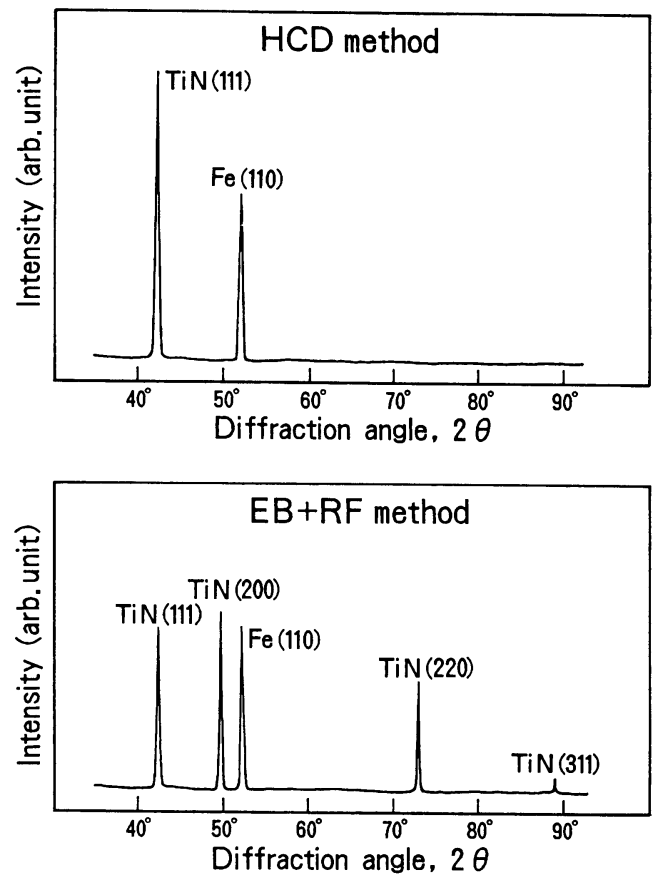

Fig. 3. X-ray diffraction charts for the TiN films coated by the HCD and EB + RF methods.

Table 1. JCPDS of TiN and $\alpha$-Fe and marks of poles in pole figures of $\mathrm{TiN}$ and silicon steel sheet.

\begin{tabular}{|r|c|c|c|}
\hline \multicolumn{4}{|c|}{ Ti N (38-1420)* } \\
\hline$d(\AA)$ & Int. & hkl & $\begin{array}{c}\text { Ma* } \\
\text { Mark }\end{array}$ \\
\hline 2.4492 & 72 & -111 & \\
\hline 2.1207 & 100 & 200 & $\square$ \\
\hline 1.4997 & 45 & 220 & \\
\hline 1.2789 & 19 & 311 & \\
\hline
\end{tabular}

\begin{tabular}{|c|c|c|c|}
\hline \multicolumn{4}{|c|}{$\alpha-\mathrm{Fe}(06-0696)^{*}$} \\
\hline$d(\AA)$ & Int. & hkl & Mark \\
\hline 2.0268 & 100 & 110 & 0 \\
\hline 1.4332 & 20 & 200 & $\square$ \\
\hline 1.1702 & 30 & 211 & \\
\hline 1.0134 & 10 & 220 & \\
\hline
\end{tabular}

* JCPDS

** Notation of poles in pole figures

この場合の集合組織において, TiNの (111) 極点困の作成に

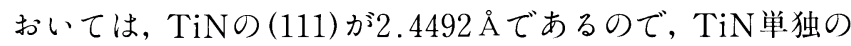
(111) 極 \{極点図中で $\boldsymbol{\Delta}$ 印を使用 $\}$ が検出されると考えられ る。こ礼に対して, 珪素鋼板 (Table 1 の-Fe)の (100) 極点 网の作成においては， $\alpha-\mathrm{Fe}$ の (200) が1.4332 ̊であるので， 琹素鎙板の (200) 極 $\{\square$ 印を使用 $\}$ と TiNの (220) 極 $\{$ Table 1 のTiNの (220)の1.4997 ゙̊， ○印を使用\}の二層の組織 が検出されると考えられる。

また，TiN膜の (110) 極点困と珪素鋼板の (110) 極点図を 问時に測定に際しては, TiNの (110) 極点困上には, TiNの (220)が1.4997 ̊であるので，TiNの (220)極 ○印を使用 $\}$

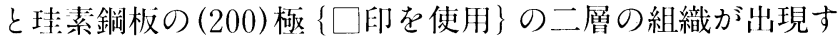


る。珪素鋼板の (110) 極点困上には, $\alpha$-Feの (110)が1.4332 であるので, 珪素鋼板の (110) 極\{○印を使用\}とTiNの (220) 極 \{○印を使用\}の二層の組織が検出されると考えられる。

\section{3. 実験結果}

Fig. 3 は, HCD法とEB+RF法によるTiN被覆一力台性 珪素鋼板の磁束密度 $\left[\mathrm{B}_{8}(\mathrm{~T})\right]$ と鉄損 $\left[\mathrm{W}_{17 / 50}(\mathrm{~W} / \mathrm{kg})\right]$ の向 上度合いをチェック後のエプスタイン試料を $30 \mathrm{~mm} \times 30 \mathrm{~mm}$ に切断後のX線回折結果を赤す。 HCD法では，TiNの強い (111) ピークのみが検出され, EB+RF法では, TiNの (111),

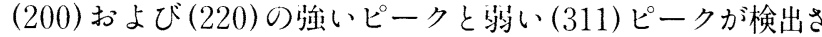

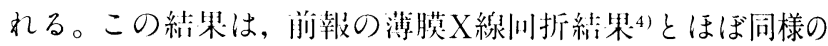

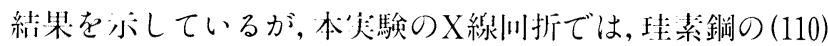
ピークが検州される。

Fig. 4 および 5 は，X線测定終うした跲料について, SSD

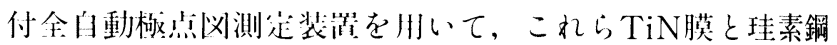
板の集合組織を闹時に测定した結果をふしたものである。 すなわち, Fig. 4 は, HCD法とEB+RF法によるTiN膜の

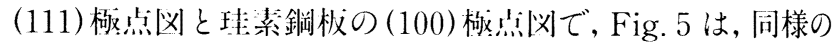

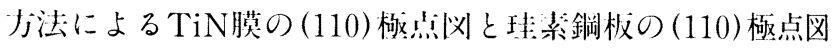
をホしたものである。

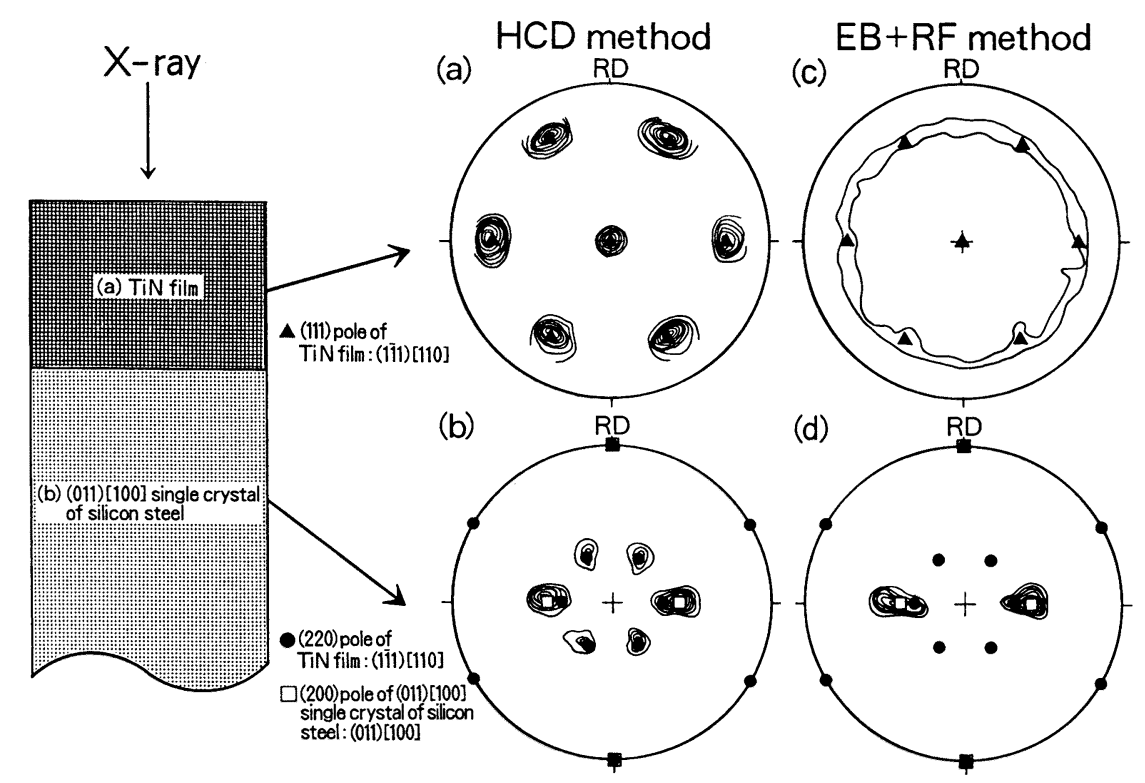

Fig. 4. (111) $)_{\text {TiN }}$ pole figure of TiN film and (100) $)_{\text {si-steel }}$ pole figure of (011)〔100] single crystal of silicon steel TiN-coated by HCD and EB + RF methods.

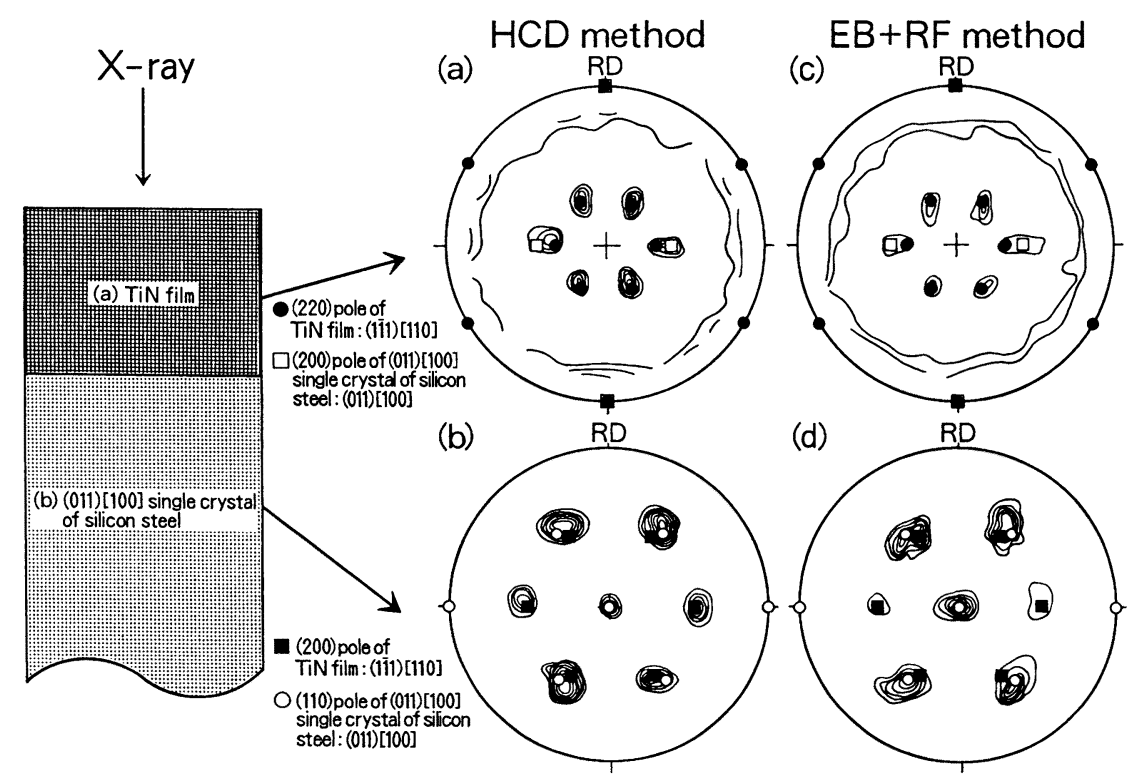

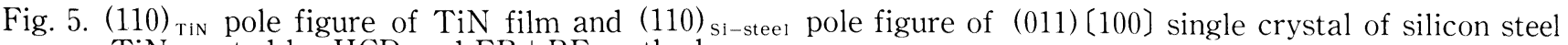
TiN-coated by HCD and EB + RF methods. 
Table 2. Ionization rates of $\mathrm{Ti}$ atoms on the substrate surface of thin films coated by the $\mathrm{HCD}$ and $\mathrm{EB}+\mathrm{RF}$ methods.

\begin{tabular}{|c|c|c|}
\hline & $\begin{array}{c}\mathrm{HCD} \\
\text { method }\end{array}$ & $\begin{array}{c}\text { EB+RF } \\
\text { method }\end{array}$ \\
\hline$\frac{\text { Ti ions }}{\text { Ti atoms }}$ & $43 \%$ & $6 \%$ \\
\hline
\end{tabular}

まず，Fig. 4 の中のHCD法による (a) TiN膜の (111) 極点 四は，(1111)〔110]方佃に極端に優先配向した集合組織を示 している。このときの(b) 珪素銅板の (100) 極点四も同様に (011)〔100〕方仿に橄端に優先唒向した集合組織を示してい る。この場命, 珪素銅板の 2 つの (200) 杫のピーク強度は, TiNの $6 \supset の(220)$ 政の中でTD軸.1:の 2 つの (220) 極も同時 に検出されるため楕仜形状となる。これに対してEB+RF法 による (c) TiN膜の (111) 粫点网は, 弱い(111) 晌内回転した 集合組織をホす寸。ま，このときの(d) 珪素鋼板の (100) 極

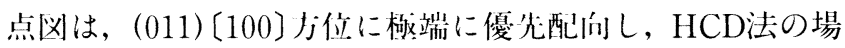

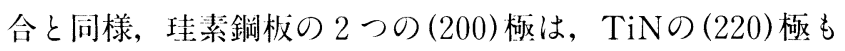
検出されるため棈仜形状をホしている。しかし，HCD法で 観察された他のト:ト 4 つのTiNの (220) 板は検出されていな い。

Fig. 5 の中のHCD法による (a) TiN膜の (110) 極点困は, (1111)〔110〕方位に優先配向した集合組織を示している。こ の場合, TiN中の 6 つの (220) 極の中でTD軸.:の 2 つのTiN の (220) 極と珪素鋼板の (200) 極が其に検出されるため楕円 形状となっているが, ピーク形状はFig. 4 の珪素鋼板の (200) 極に比較し非常に弱い。このときの(b) 轨素鎆板の (110) 極 点网は，(011) [100]方位に杫端に優先配向した集合組織を 示している。この場命, 珪素鎆板のト下の 4 つの (110) 極は, TiNの (200) 杫と其に検出される。これに対してEB+RF法

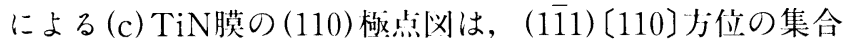
組織であるが，HCD法に比較して弱くなっている。また， このときの (d) 珪素銅板の (110) 板点四は，(011)〔100〕方位 に極端に優先配们しているが, TiNの (200) 跑は, HCD法の 場合に比較して弱くなっている。

Table 2 にはHCD法とEB+RF法でTiのイオン化率を測 定した結果を亦すが，HCD法では4 $43 \%$ の高イオン化率であ る。これに対してEB+RF法では6\%の小さな值である。本 実験のEB+RF法のイオン化率の測定結果は黄, 田畑8 らの

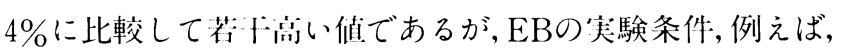
走查速度等によっても僅かの变化が考えられるので，この

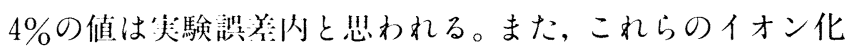

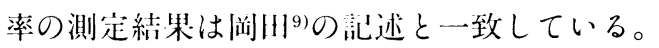

\section{4. 考察}

前報出の一台のイオンプレーティング装置内でHCD法と
$\mathrm{EB}+\mathrm{RF}$ 法の二種類の方法により TiN被覆した一方向性珪 素鋼板の磁気特性および磁区構造の磁壁間隔の比較, ある いはTiN膜の電顕観察, X線回折, 色調, および化学分析に よる膜質の比較ならびに本実験のイオン化率の比較から， $\mathrm{HCD}$ 法によるTiNのコーティング膜は, $\mathrm{EB}+\mathrm{RF}$ 法よりも 優れていること，そしてそのようなTiN膜は，緻密で平滑 性に優れ，再現性良くコーティングできるとともにTiのイ オン化率も $43 \%$ と高いことが明らかとなった。これに对し て $\mathrm{EB}+\mathrm{RF}$ 法では, 磁気特性が $\mathrm{HCD}$ 法の約半分程度し改善 されず，このTiN膜も大きい粒子で構成され，表面が非常 に粗く, Tiのイオン化率も6\%と低いことも明らかとなった。

なお，本実験のコーティング手法によるTiN膜の集合組 織は，実験方法で詳述したように，理想的な (011)〔100〕方 位を有する珪素鋼単結晶マトリックス上に, HCD法を用い てTiNをコーティングした場合においてのみ, Fig. 4 および 5 のような極端な集合組織の差が得られ，通常の一方向性

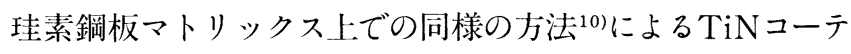
イングではこのような極端な集合組織の差が得られなく, 且つTiNの極点図中の各極のピーク強度もまちまちである。 すなわち，TiNコーティングする際に使用する珪素鋼、ト リックスの方位集積度の差によって，その上にューティン グされたTiN膜の集合組織の集積度も大きく变化すると考 えられる。

本実験の集合組織の測定結果から，HCD法による珪素鋼 板上のTiN膜は (1111) [110〕方位に強く配向した集合組織を 示す。すなわち, HCD法においては，珪素鋼マトリックス との整 合【 $(1 \overline{1} 1)_{\mathrm{TiN}} / /(011)_{\mathrm{Si}-\mathrm{stee} 1,[110]_{\mathrm{TiN}} / /}$ $[100]_{\mathrm{si}_{-} \text {stee }{ }^{11}}{ }^{11}$ 】を満足して優先成長するのに較べて，EB+ RF法では, TiNの (1111)〔110〕方位の集積度が悪く珪素鋼、 トリックス整合が良好な状態ではないため，結果として磁 気特性の向上や密着性が悪くなると考えられる。本実験に おいては一台のイオンプレーティング装置内でHCD法とEB+ RF法の二種類の方法により同一レベルの磁気特性を有する 珪素鋼板上のTiNのコーティング実験を行った後, 同じ条 件で集合組織を測定しているので，これら TiN膜の集合組 織の顕著な相違は, コーティング手法の相違によると考え られる。

次に, HCD法でューティングしたTiN膜は, EB+RF法 と異なり，何故維密で平滑性に優れているのかについて考 察する。まず，Tiのイオン化率の測定結果から，HCD法で は，43\%の1高イオン化率の高密度プラズマ雲囲気中での コーティングであること, 次に, X線構造解析および集合組 織の測定結果から, (2)(1111)〔110〕方位に極端に配向したTiN

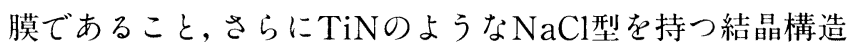
においては(3)(111)の表面エネルギー12)が他の(100) あるいは (110)よりも大きく, 且つ成長速度も速いことが指摘できる。 TiNの (111) 面は最稠密面であり, Tiと Tiの原子間隔が最近 接間隔である。したがって，TiN膜の(111) 面上においては 
Ti原子が最稠密に配列しているため, TiN膜が緻密で, 平 滑になると考えられる。以上, HCD法でのTiNューティン グは，上記のこれら(1)，(2)および(3)の条件を満足させるこ とができるために，緻密で平滑性に優れたTiN膜を有する イオンプレーティングが可能であると推論される。

最後に, HCD法でTiNューティングした場合，一方向性 珪素鋼板の磁気特性や密着性は, $\mathrm{EB}+\mathrm{RF}$ 法に比較して顕著 に向上するのかに関してである。まず, (1)珪素鋼板上のTiN のセラミック膜は, 珪素鋼マトリックスとの密着性の確保 が最重要であり,この密着性【HCD法では, 珪素鋼マトリッ クス上でTiN膜の最適な混合層を作り出すことが叮能】が確 保された状況で，(2)珪素銅マトリックストでTiNとの艮い

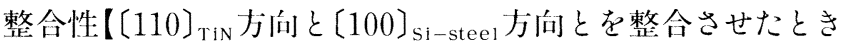
のミスフィットは，4.5\%】を持って (1111)〔110〕方位に優先 成言したTiN膜は，〔100]の一軸少向に強力な弾性張力の付 与が叮能であるため, (3)極端な磁区細分化を達成し, 結果 として一方们性珪素鎆板の超低鉄損化が可能になると考え られる。

\section{5. 結言}

一台のイオンプレーティング装置内でHCD法と $\mathrm{EB}+\mathrm{RF}$ 法の二種類の方法により一方向性珪素鋼板表面上: にTiNを 被覆して磁気特性を調查した後, SSD付全自動極点汹测定 装置を用いて，これら TiN膜と珪素鋼板の二層の集合組織 を同時に测定した。また，両手法におけるTiのイオン化率 を測定してTiNの膜質の相違も比較検討した結果, 次のこ とが明らかとなった。

（1）HCD法によるTiN膜の (111) 極点罒は, (1111)〔110]力 位に極端に優先配向した集合組織を示すとともに，このと きの (011)〔100]方位の珪素鈰単結晶の (100) 極点困も同様に

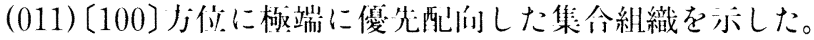

( 2 ) これに対してEB+RF法によるTiN膜の (111) 極点図 は，(111) 面内叮転した集合組織であるが，HCD法に比較し て弱く，ランダムな集令組織であった。またこのときの

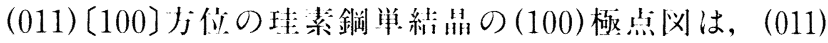

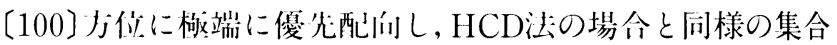
組織をふくした。

(3)（1）および ( 2 ) 結果から判るように, TiN膜と珪素 鋼マトリックスの二層の集合組織は, SSD付全自動極点図 测定装置を䏘いて，间時に测定することが叮能である。

（4）HCD法のTiN膜は, 基板へ到達寸るTiのイオン化率 が $43 \%$ と高く，EB+RF法でのTiN膜はTiのイオン化率も 6\%と低かった。

（5）HCD法によるTiN膜は，(111)〔110〕力j位に優先配向 した集合組織をぶしたのに較べて, EB＋RF法では，配问性 の弱い集合組織が得られた。

\section{文献}

1) Y.Inokuti, K.Suzuki and Y.Kobayashi : Mater. Trans. JIM., 33 (1992), 946.

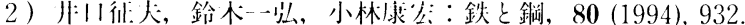

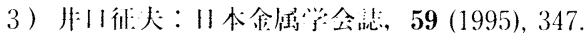

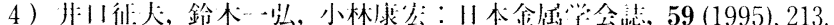

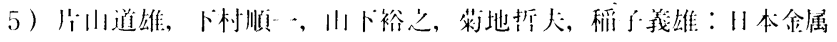
兴会会解, 33 (1994), 625。

6 ) T.Nozawa, T.Yamamoto, Y.Matsuo and Y.Ohya: IEEE Trans., Mag-14 (1978), 252

7) S.Komiya and K.Tsuruoka: Japan J.Appl. Phys. Suppl., 2 (1974), 415.

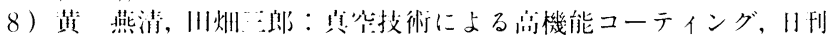

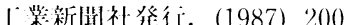

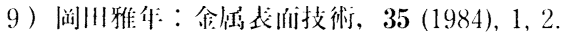

10）术発花データ

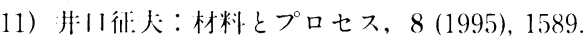

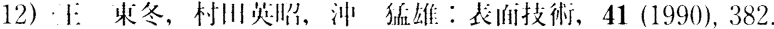

